\title{
Profitability Ratio Analysis and its Effect's to Firm Value in the Food and Beverage Industry in Indonesian Stock Exchange
}

\author{
Sitti Murniati \\ STIE Wira Bhakti Makassar, Indonesia \\ Graduate Student of Moeslim Indonesian University, Indonesia \\ sittimurniati@ymail.com
}

\begin{abstract}
This study aims to analysis the profitability ratio consisting of net profit margin, basic earning power and contribution margin and its effect on firm value in Food and Beverage industry. The data in this study, obtained from the capital market information center with the object of research in Food and Beverage industry listed on the Indonesian Stock Exchange. This study uses secondary data sourced from the financial statements in Food and Beverage industry, published by the Indonesian Stock Exchange in 2012 until 2015. The data analysis method used is multiple regression analysis. After analysis of all data, the result of research is as follows: 1) net profit margin has a positive and significant effect to price book value which means that management experience success in operational matter and will result in increasing investor trust to invest in Food and Beverage industry, 2 ) basic earning power has a positive and insignificant effect to price book value which means that the working capital in the issuer is only the operating capital or operating assets, as well as the profit that is accounted for only from the operating income of the company is net operating income, and 3) contribution margin has a negative and significant effect to price book value which means that the issuer has not been able to generate profits from the sales of its product caused by the selling price of down so that the contribution margin amount cannot be used to cover all fixed costs so that there is loss in the period.
\end{abstract}

Keywords: Net Profit Margin, Basic Earning Power, Contribution Margin and Price Book Value

\section{Introduction}

The firm value analysis will be provided information's useful to investors in assessing the future prospects of the company in generating profits. For companies that have good firm value will give a positive signal to rising stock prices. The firm values that have issued their shares to the public in the capital market will be reflected in the company stock price in the capital market. If the company has good prospects in the future, then the stock price will increase. Conversely, if the company is rated by shareholders as less prospective then the stock price will decrease, (Mardiyati et al., 2012). Profitability is one of the factors that affect the firm value. Profitability is the company's ability to generate profits at certain levels of sales, assets and capital (Hanafi, 2013). One important indicator for investors in assessing the prospects of the company in the future is to see how far the growth of company profitability. The profitability of a company is one way to judge precisely how far the rate of return to be derived from its investment activity. Weston and Copeland (2008), profitability can reflect the benefits of financial investment that mean profitability affects the firm value because increasingly large internal source. The better growth in company profitability means the prospect of the company in the future is rated better the firm value will be rated better of investors. If the company's ability to generate profit increases, then the stock price will also increase. A company that have high profitability and managed to record an increasing profit will show that the company is performing well so that it will create a positive response to shareholders and make the company stock price increases. High profitability also shows good company prospects that will create positive sentiment for shareholders and firm value will be increase (Sujoko and Soebiantoro, 2007). This is because profitability is the end result of a number of policies and management decisions of the company.

\section{Literature Review}

Profitability. Brigham and Houston (2011), profitability is the end result of a series of policies and management decisions, where these policies and decisions concern the source and use of funds in running the company operations are summarized in the balance sheet and elements of the balance sheet. The better profitability will make investors become more confident to invest in the company. Good profitability will provide benefits to the company and shareholders. For the company, will get an injection of funds from investors and increase the market of firm value. Profitability is the ability of the company in obtaining profit 
in a certain period (Susanti, 2010). The high or low profit earned by the company is also an indicator of company performance management. The higher the profit earned, the shareholders have the perception that the company has made efficiency in using assets owned, so that it can generate profit (Mardiyati et al., 2012). In this study profitability is measured by using net profit margin (NPM), basic earning power (BEP) and contribution margin (CM). Hanafi (2013), state that net profit margin (NPM) is a ratio that measures the rupiah profit earned by each one dollar sales. The greater NPM, then company performance will be more productive, so it will increase investor confidence to invest in company. Hanafi (2013), state that basic earning power (BEP) is a ratio that measures company ability to earn profit that is measured from the amount of profit before interest and tax deductions compared to total assets. The greater this ratio the better of company condition to earn profit. Hanafi, (2013), state that contribution margin (CM) measure the company ability to earn profit that will cover fixed cost or other operating cost. With knowledge of this ratio management can control expenditure for fixed cost or operating cost so that company can generate profit.

Firm Value: Alfredo (2011) explains that firm value is an important concept for investors, because it is an indicator for the market in assessing as whole the company. Kusumadilaga (2010) states that firm value is the price would be paid by prospective buyer if the company is sold. Tandelilin (2011) in stock valuation there are three types firm value are book value, market value and intrinsic value. Martalina (2011), some value concept that explains firm value are nominal value, market value, intrinsic value, book value and liquidity value. Nominal value is the value state formally in the budgeting of association of the company, mentioned explicitly in the company's balance sheet and also written clearly in the collective share letter. In firm value research is measured by using price book value (PBV) ratio. This ratio attributes the total market capitalization of the company to the shareholders' funds. This ratio compares the value of the stock market with the investment of shareholders in the company. Brigham and Houston (2011) the ratio of a stock's market price to its book value gives an indication of the investor's view of the firm. Husnan (2009) said price book value (PBV) can be used to measure the value of the company, the greater price book value (PBV) ratio, the higher the company is judged by the investors.

\section{Methodology}

Research Design: The design of this study is to determine whether the profitability ratio are measured by net profit margin (NPM), basic earning power (BEP) and contribution margin (CM) as independent variables affect the firm value measured by price book value (PBV) ratio as dependent variable.

Population and Sample: The population of this research is Food and Beverage industry which listed in the Indonesian Stock Exchange for 4 years that is year 2012 until year 2015 which amounts to 14 companies. Based on sampling technique using certain criterion, the research sample is 11 companies with 44 observations.

Types and Sources of Data: The type of data in this study is quantitative data in the form of numerical financial statements used as a basis to describe all indicators of variables analyzed. The data used is secondary data and sourced from the Indonesian Capital Market Directory (ICMD) or through the website www.idx.co.id in the form of financial statements Food and Beverage industry listed in the Indonesian Stock Exchange.

Collection Technique of Data: The technique used is the documentation techniques. The go-public industry financial statements are selected as an analytical unit with the reason to obtain data and can access data in complete.

Data Analysis: The method of analysis used is multiple regression analysis. The use of this method with the consideration the pattern of relationships between variables in this study are correlative and causality, with the formula by Sugiyono (2013) is: $\mathbf{Y}=\mathbf{a}+\mathbf{b}_{1} \mathbf{X}_{\mathbf{1}}+\mathbf{b}_{2} \mathbf{X}_{\mathbf{2}}+\mathbf{b}_{3} \mathbf{X}_{\mathbf{3}}$

Explanation:

$\mathrm{Y}=$ Price Book Value (PBV)

$\mathrm{X}_{1}=$ Net Profit Margin (NPM)

$\mathrm{X}_{2}=$ Basic Earning Power (BEP) 


$$
\begin{array}{ll}
\mathrm{X}_{3} & =\text { Contribution Margin }(\mathrm{CM}) \\
\mathrm{a} & =\text { Constanta } \\
\mathrm{b}_{1}, \mathrm{~b}_{2}, \mathrm{~b}_{3}=\text { Coefficients Regression }
\end{array}
$$

\section{Results}

Profitability measured by net profit margin (NPM) in the Food and Beverage industry listed in Indonesian Stock Exchange has fluctuated. The average of the highest NPM for 11 companies is seen in 2013 is $11.59 \%$. The average of the lowest NPM for 11 companies is seen in 2014 is $10.24 \%$. Profitability measured by basic earning power BEP in the Food and Beverage industry listed in Indonesian Stock Exchange has fluctuated. The average of the highest BEP for the 11 companies seen in 2013 is $20.28 \%$. The average of the lowest BEP for 11 companies seen in 2015 is $14.06 \%$. Profitability measured by contribution margin (CM) in the Food and Beverage industry listed in Indonesian Stock Exchange has fluctuated. The average of the highest CM for 11 companies is seen in 2012 is $28.83 \%$. The average of the lowest CM for 11 companies is seen in 2012 is $26.80 \%$. The firm value as measured by price book value (PBV) in the Food and Beverage industry listed Indonesian Stock Exchange has fluctuated. The average of the highest PBV for 11 companies is seen in 2014 is 8.29\%. The average of the lowest PBV for 11 companies is seen in 2015 is $5.02 \%$.

Test of Multiple Linear Regressions: Multiple linear regression test is the influence of independent variable to dependent variable. The magnitude of the influence of independent variables on the dependent variable can be calculated through multiple regression equations is:

$Y=1,948+1,074 X_{1}+0,180 X_{2}-0,349 X_{3}$

The regression equation can be interpreted as follows:

- The coefficient of 1,948 means that if the profitability ratio measured by net profit margin (NPM), basic earning power (BEP) and contribution margin (CM) is constant, then firm value as measured by price book value (PBV) will not change.

- The coefficient b1 of 1,074 means any increase in profitability ratio measured by net profit margin (NPM), then firm value as measured b-+y price book value (PBV) increased by 1,074 . NPM variable is the dominant variable affecting PBV because it has value of Standardized Coefficients Beta bigger that is 0,885 .

- The coefficient b2 of 0,180 means any increase in profitability ratio measured by basic earning power (BEP), then firm value as measured by price book value (PBV) increased by 0,180.

- The coefficient b3 of -0.349 means any increase in profitability ratio measured by contribution margin (CM), then firm value as measured by price book value (PBV) decreased by 0,349.

Simultaneous Testing (Test F): The test is conducted to test whether there is a significant difference between profitability ratio measured by net profit margin (NPM), basic earning power (BEP) and contribution margin (CM) to firm value as measured by price book value (PBV).

Table 1: Simultaneous Testing (Test F)

ANOVA $^{\mathbf{b}}$

\begin{tabular}{lllllll}
\hline Model & & Sum of Squares & Df & Mean Square & F & Sig. \\
\hline 1 & Regression & 2902.082 & 3 & 967.361 & 22.375 & $.000^{\mathrm{a}}$ \\
& Residual & 1729.372 & 40 & 43.234 & & \\
& Total & 4631.454 & 43 & & & \\
\hline
\end{tabular}

a. Predictors: (Constant), Contribution Margin , Basic Earning Power , Net Profit Margin

b. Dependent Variable: Price Book Value

Source: Output SPSS, 2017

Based on the table above, it shows the significant value $F$ is 0,000 . Based on testing criteria that if the probability value is $<0.05$, then $\mathrm{H}_{\mathrm{a}}$ is accepted. It can be concluded that the variable of profitability ratio 
measured by net profit margin (NPM), basic earning power (BEP) and contribution margin (CM) simultaneously significant affect the firm value as measured by price book value (PBV). It is shown on a significant $F$ value is 22,375 with significant $=0,000<0,05$. So if net profit margin (NPM), basic earning power (BEP) and contribution margin (CM) increase, the price book value (PBV) will also increase.

The coefficient of determination (R2): Coefficient of determination analysis performed to see how big a percentage of variables influence of the profitability ratio measured by net profit margin (NPM), basic earning power (BEP) and contribution margin (CM) against to firm value measured by price book value (PBV).

Table 2: The coefficient of determination (R2)

Model Summary

\begin{tabular}{|c|c|c|c|c|c|c|c|c|c|}
\hline \multirow[b]{2}{*}{ Model } & \multirow[b]{2}{*}{$\mathbf{R}$} & \multirow{2}{*}{$\begin{array}{l}\mathrm{R} \\
\text { Square }\end{array}$} & \multirow{2}{*}{$\begin{array}{l}\text { Adjusted } \\
\text { R } \\
\text { Square }\end{array}$} & \multirow{2}{*}{$\begin{array}{l}\text { Std. Error } \\
\text { of the } \\
\text { Estimate }\end{array}$} & \multicolumn{5}{|c|}{ Change Statistics } \\
\hline & & & & & $\begin{array}{l}\text { R Square } \\
\text { Change }\end{array}$ & $\begin{array}{l}\text { F } \\
\text { Change }\end{array}$ & df1 & df2 & $\begin{array}{l}\text { Sig. F } \\
\text { Change }\end{array}$ \\
\hline 1 & $.792^{a}$ & .627 & .599 & 6.57528 & .627 & 22.375 & 3 & 40 & .000 \\
\hline
\end{tabular}

a. Predictors: (Constant), Contribution Margin , Basic Earning

Power, Net Profit Margin

Source: Output SPSS, 2017

Based on the table above, it shows that the value of $\mathrm{R}$ square obtained is 0,627 which showed that the firm value measured by price book value (PBV) influenced by variables of profitability ratio measured by net profit margin (NPM), basic earning power (BEP) and contribution margin (CM) is 62,7 \%, and the remaining $37,3 \%$ is influenced by other variables that have not been examined in this study. By looking at the high coefficient indicates the effect of variables, the independent variable on the dependent variable was also high at $62,7 \%$.

Partial Test (Test $\mathrm{t}$ ): Partial test ( $\mathrm{t}$ test) was performed to determine whether a variable net profit margin (NPM), basic earning power (BEP) and contribution margin (CM) affect the price book value (PBV) partially.

Table 3: Partial Test Results (Uji t) Coefficients $^{\mathrm{a}}$

\begin{tabular}{lllllll}
\hline \multicolumn{1}{c}{ Model } & & \multicolumn{2}{c}{$\begin{array}{l}\text { Unstandardized } \\
\text { Coefficients }\end{array}$} & \multicolumn{2}{c}{$\begin{array}{l}\text { Standardized } \\
\text { Coefficients }\end{array}$} & \\
\hline 1 & & B & Std. Error & Beta & t & Sig. \\
\hline & (Constant) & 1.948 & 1.983 & & .983 & .332 \\
& Net Profit Margin & 1.074 & .394 & .885 & 2.727 & .009 \\
& Basic Earning Power & .180 & .151 & .286 & 1.193 & .240 \\
& Contribution Margin & -.349 & .115 & -.560 & -3.035 & .004
\end{tabular}

a. Dependent Variable: Price Book Value

Source: Output SPSS, 2017

The table above shows the t-test result are: The profitability ratio as measured by net profit margin (NPM) has positive and significant effect on firm value as measured by price book value (PBV), based on the test result, it is obtained $t$-value of 2,727 with significance level 0,009 . The profitability ratio as measured by basic earning power (BEP) has positive and insignificant effect on firm value as measured by price book value (PBV), based on test result, it is obtained t-value of 1,193 with significance level 0,240 . The profitability ratio as measured by contribution margin (CM) has negative and significant effect on firm value as measured by price book value (PBV), based on test result, it is obtained t-value of -3.035 with significance level 0,004 .

Effect of Net Profit Margin to Price Book Value: Profitability ratio as measured by net profit margin has positive and significant effect to firm value as measured by price book value in Food and Beverage industry 
listed in Indonesian Stock Exchange. This means that when net income rises, then total sales will increase, it indicates that management experience success in terms of operations and this will lead to increased investor confidence to invest in the food and beverage industry. The greater the ratio of net profit margin, the better the company's ability to earn a high profit. Rinati (2008) states that the greater the net profit margin then the company performance will be more productive, so it will increase investor confidence to invest in the company, with the increase of investors will affect the stock price of the company that will increase. The results of this study support the research Mardiyati et al (2012) which shows that net profit margin has positive and significant effect in firm value. The higher the value of net profit margin the higher net profit generated from each sale and this shows that the performance of management within the company either, of course will attract investors to invest. The more investors who invest in the company then the stock price of the company will rise. But the results of this study do not support the research undertaken by Pratiwi and Priyadi (2014) which shows that the net profit margin does not affect the size of the resulting return that will directly affect the firm value that will decrease. This is because the company is not able to generate profits for the company that affects investors and potential investors to make investments. At this time, investors are not willing to buy stocks with high prices with a low net profit margin value of the company, resulting in net profit margin does not affect the company rate of return. This is because the high level of net profit margin does not necessarily attract investors to invest.

Effect of Basic Earning Power to Price Book Value: Profitability ratio as measured by basic earning power has positive and insignificant effect to firm value as measured by price book value in food and beverage industries listed in Indonesian Stock Exchange. This means that the Food and Beverage industry has not been able to generate profits from assets before taxes and leverage, since large profits have not become a measure that the company has worked efficiently because it can efficiently be known by comparing profits earned by companies with wealth or capital to generate profits. This means that the capital working in a company is only the operating capital or operating assets, as well as the profit that is taken into account only the profits derived from the operating company that is net operating income. Brigham and Houston (2011) stated basic earning power shows the ability of the company to generate profits from the company's assets, before the influence of taxes and leverage which means if basic earnings power increases, then the company's profits will increase. The results of this study support the research Fitriyanti (2016) which shows that basic earning power has no significant effect on stock return. It can prove how much asset ability the company has to generate returns or earnings. The increasing BEP value shows an increase in the ability of the company assets to generate operating profit. Thus the high BEP variable so the profit generated on stock return will increase as well so that investors invest in the company. This means that if the basic earning power is higher, the more likely the value of the firm increases as reflected by the high valued stock price.

Effect of Contribution Margin to Price Book Value: Profitability ratio as measured by contribution margin has a negative and significant impact to firm value as measured by the price book value in Food and Beverage industry listed in the Indonesian Stock Exchange. This means that the Food and Beverage industry has not been able to generate profits from sales of its products caused by the selling price down so that the amount of contribution margin cannot be used to cover all fixed costs and have not been able to generate profits resulting in loss in the period concerned. Sunarto (2014), the change of selling price is very influential to the contribution margin, where if the selling price rises, the contribution margin will increase and the profit level of the company will rise also. Conversely, if the selling price decreases, the contribution margin will also decrease which means the profit becomes low followed by the decrease of firm value. The results of this study do not support the research Silvana et al. (2014) which shows that contribution margin can be used for sales planning and profit, making it easier for management in decision making. Contribution margin for sales planning is used as a sales decider at break event point, expected rate of return and margin of safety of the sales conditions and who determines which product sales can optimize earnings. For companies that produce and sell a variety of products, this analysis is very useful to know the amount of profits generated from all levels of sales and sales of each product. This is because the greater the contribution margin and the profit generated, the company will be willing to spend more on producing the highest margin contribution product, and the company is willing to spend more on marketing products that have high contribution margin in order to optimize profit. 


\section{Conclusion}

Based on the data analysis that has been described in previous chapters, it can be concluded as follows: 1 ) profitability ratio as measured by net profit margin has positive and significant effect to firm value as measured by price book value, 2) profitability ratio as measured by basic earning power has positive and insignificant effect to firm value as measured by price book value, and 3) Profitability ratio as measured by contribution margin has a negative and significant impact to firm value as measured by the price book value.

\section{References}

Alfredo, M. (2011). The Effect of Financial Performance on Firm Value With Dividend Policy As Moderating Variables In Manufacturing Companies In Indonesian Stock Exchange. Denpasar. Udayana University.

Brigham, E. F. \& Houston, J. F. (2011). Fundamentals of Financial Management. (Interpreting: Ali Akbar Yulianto). Salemba Four. Jakarta.

Fitriyanti, I. (2016). Effect of Return On Equity, Basic Earning Power, Price Earning Ratio and Price To Book Value On Stock Return In Company LQ 45 Period 2010-2014. Scientific Articles. STIE Perbanas. Surabaya.

Hanafi, A. H. (2013). Financial Statement Analysis. UPP STIM YKPN. Yogyakarta.

Husnan, S. (2009). Financial Management: Theory and Application (Short-Term Decision). BPFE. Yogyakarta.

Kusumadilaga, R. (2010). The Influence of CSR on Corporate Value With Profitability As Moderating Variable In Manufacturing Companies Listed In Indonesian Efef Exchange. Faculty of Economics Diponegoro University of Semarang.

Mardiyati, U., Ahmad, G. N. \& Putri, R. (2012). Influence of Dividend Policy, Debt and Rentability Policy on Firm Value of Manufacturing Listed in BEI Period 2005-2010. Journal of Indonesian Science Management Research (JRMSI), 2(1).

Martalina, L. (2011). Influence profitability And Company Size to Firm Value with Capital Structure as Variable Intervening at Manufacturing Companies Listed in Indonesian Stock Exchange. Faculty of Economics. State University of Padang.

Pratiwi, T. M. \& Priyadi, M. P. (2014). Analysis of Effect of Company Financial Performance on Stock Return. Journal of Scientific \& Accounting Research, 3(10). STIE Indonesia. Surabaya.

Silvana, F., Nengah, S. \& Topo, W. (2014). Contribution Margin Analysis to Determine the Sales Rate of the Product in Order to maximize Profit. Journal of Business Administration (JAB), 15(2). Faculty of Administration. Brawijaya University. Malang.

Sugiyono. (2013). Business Research Methods (Quantitative Approach, Qualitative and R\&D). Publisher: Alfabeta. Bandung.

Sujoko. \& Soebiantoro, U. (2007). Influence of Stock Ownership Structure, Leverage, Internal Factor And Exterminate Factor To Firm Value. Journal of Management and Entrepreneurship, 9(1).

Sunarto (2014). Management Accounting. UPP AMP YKPN. Yogyakarta.

Susanti, R. (2010). Analysis of Factors Affecting Firm Value. Faculty of Economics. Diponegoro University.

Tandelilin, E. (2011). Investment Analysis and Portfolio Management. BPFE. Yogyakarta.

Weston, J. F. \& Copeland, E. T. (2008). Financial management. Ninth Edition. Bina Aksara. Jakarta. 